\title{
Age- and Size-Related Changes in the Inner Ear and Hearing Ability of the Adult Zebrafish (Danio rerio)
}

\author{
Dennis M. Higgs, ${ }^{1}$ Marcy J. Souza, ${ }^{1,2}$ Heather R. Wilkins, ${ }^{1,3}$ Joelle C. Presson, ${ }^{1}$ And \\ ARTHUR N. POPPER ${ }^{1}$ \\ ${ }^{1}$ Department of Biology, University of Maryland, College Park, MD 20742, USA \\ ${ }^{2}$ College of Veterinary Medicine, North Carolina State University, Raleigh, NC 27695, USA \\ ${ }^{3}$ Department of Cell and Molecular Physiology, University of North Carolina, Chapel Hill, NC 27599, USA
}

Received: 13 July 2001; Accepted: 29 August 2001; Online publication: 12 November 2001

\begin{abstract}
Fishes, unlike most other vertebrate groups, continue to add sensory hair cells to their ears for much of their lives. However, it is not clear whether the addition ever stops or how the addition of sensory cells impacts hearing ability. In this article, we tested both questions using the zebrafish, Danio rerio. Our results not only have important implications for understanding the consequences of adding sensory receptors, but these results for normal zebrafish also serve as valuable baseline information for future studies of select mutations on the ear and hearing of this species. Our results show that hair cell production continues in uncrowded zebrafish up to 10 months of age (about one-third of a normal life span), but despite this addition there is no change in hearing sensitivity or bandwidth. Therefore, hearing is not related to the number of sensory cells in the ear in juvenile and adult animals. We also show that despite no net addition of hair cells after about 10 months, hair cells are still being produced, but at a lower rate, presumably to replace cells that are dying. Moreover, crowding of zebrafish has a marked impact on the growth of the fish and on the addition of sensory cells to the ear. We also demonstrate that fish size, not age, is a better indicator of developmental state of zebrafish.
\end{abstract}

Keywords: auditory hair cells, ABR, zebrafish, cell death, neurogenesis, development

Correspondence to: Dennis M. Higgs, Ph.D. • Department of Biology - University of Maryland - College Park, MD 20742. Telephone: (301) 405-6903; fax: (301) 314-9358; email: dh201@umail.umd.edu

\section{INTRODUCTION}

New hair cells are produced in the ears of fishes for months or years after hatching (Corwin 1981, 1983; Popper and Hoxter 1984; Lombarte and Popper 1994). However, it is still not known whether proliferation continues for the duration of a fish's life. Significant postembryonic auditory hair cell addition in fishes is clearly different from findings in birds and mammals. Birds and mammals do not add hair cells to the auditory end organ after final maturation under normal conditions (Ruben 1967; Corwin and Cotanche 1988; Ryals and Rubel 1988) although birds do add hair cells throughout life to vestibular organs (Jørgensen and Mathiesen 1988; Roberson et al. 1992) and to auditory organs after damage (Cotanche 1987; Cruz et al. 1987; Corwin and Cotanche 1988; Ryals and Rubel 1988).

Related to the postembryonic addition of sensory hair cells is the question of whether these changes affect hearing abilities. Hearing has been shown to improve in some vertebrates with age (e.g., frogs: Boatright-Horowitz and Megela Simmons 1995; geckos: Werner et al. 1998; birds: Golubeva and Tikhonov 1985; mammals: Rübsamen 1992; McFadden et al. 1996; Reimer 1996; Hill et al. 1998), at least until maturation of the auditory region of the ear is complete. There are few studies, however, relating hearing and growth in fish. The addition of sensory hair cells to an auditory end organ in elasmobranchs is correlated with an increase in sensitivity of the nerve branch innervating that end organ (Corwin 1983). Other studies examining auditory abilities in fish either found a change in hearing ability with growth (Kenyon 1996; 
Iwashita et al. 1999; Wysocki and Ladich 2001) or found no change between different sizes of fish (Popper 1971). However, only the elasmobranch study (Corwin 1983) directly correlated the responses of the ear with changes in the number of sensory hair cells.

Zebrafish have become a particularly important model for vertebrate genetic studies, and there is an increasing number of studies on the genetics and development of the ear in this species (Granato et al. 1996; Riley and Grunwald 1996; Whitfield et al. 1996; Riley and Moorman 2000). In spite of this importance, there have been few studies on the zebrafish auditory system (Waterman and Bell 1984; Platt 1993; Haddon and Lewis 1996) and no studies examining zebrafish hearing ability. The purpose of the current study was to examine developmental changes in the number of sensory hair cells in the saccule of zebrafish (Danio rerio) aged three months to over two years, representing animals from sexual immaturity to adulthood. We also examined the hearing ability of zebrafish to investigate possible relationships between hair cell number and hearing ability. In addition, we wanted to test the hypothesis that hair cell addition slows or stops when overall growth of the fish stops. This hypothesis is particularly important if zebrafish become models for genetic effects on adult or aging ears since maintenance of fish under conditions where growth is artificially slowed (e.g., crowded conditions) could have profound effects on interpretation of results.

\section{MATERIALS AND METHODS}

\section{Inner ear structure}

Zebrafish between the ages of three weeks and six months were obtained from Eckwell Water Life (Gibsonton, FL). The animals were hatched and raised, until the time of shipping, in large uncrowded ponds where the growth rate was unrestricted. Once in the laboratory, the fish were divided into uncrowded (fewer than 10 fish per $37.85 \mathrm{~L}$ tank) and crowded (more than 30 fish per $37.85 \mathrm{~L}$ tank) groups and kept in these groups until used in experiments. As fish were used in experiments they were replaced so that the density of the fish in the tank remained unchanged. While it is possible that fish in the uncrowded tanks became more crowded with growth, we do not feel this was a significant concern in the current study because of the small size of the fish relative to the tank in which they were housed (Innes 1956). Fish were fed daily and the tanks maintained at $23^{\circ} \mathrm{C}$. The fish were kept on a 12:12 light:dark cycle and monitored daily. Animal use was under the supervision of the University of Maryland Institutional Animal Care and Use Committee.
Fish were prepared for microscopic analysis by euthanizing with MS-222 (an anesthetic for coldblooded vertebrates). The total length (tip of snout to tip of tail) was determined for each animal used in this study. The jaw and tissue covering the otic capsules were then removed and the remaining tissue, containing the ear, was placed in $2.0 \%$ paraformaldehyde and used as described below.

Phalloidin and hair cell counts. The number of saccular hair cells was determined for uncrowded zebrafish aged $3,6,10,15$, and 18 months and for crowded zebrafish aged 10 and 27 months. The saccule is thought to be the primary auditory endorgan in this group (reviewed in Platt and Popper 1981; Fay 1988b), so only saccular hair cells were considered here. At least three fish were used for each age group, with up to six for the youngest animals where more specimens were available. Fish were sacrificed and the tissue fixed in $2 \%$ paraformaldehyde for 30 minutes. The saccules were then removed from the heads, rinsed in phosphate buffer, and placed in Oregon Green Phalloidin (Molecular Probes, Inc., Eugene, OR) for 30 minutes. Phalloidin selectively binds to the actin in hair cell bundles, making them easy to identify. The tissue was rinsed in phosphate buffer, mounted using Prolong Antifade (Molecular Probes, Inc.), and examined using a Biorad MC 1024 confocal microscope. Low power images (40X objective) of the saccular epithelium were taken and then manually merged to get a view of the total epithelium (Fig. 1). The total area of the epithelium was determined using a computerized digitizer and Arc View planimetric software.

Since there are several thousand hair cells on each saccular epithelium, it was necessary to estimate total numbers of cells rather than attempt to count each cell. This method, while giving only an estimate of hair cell number, is reasonable to use when working within a single species where density of hair cells is similar between specimens (Popper and Hoxter 1984) and does not change as the fish grow (see Results). Hair cell counts were obtained from 14 preselected locations on the magnified montage of the epithelium (Fig. 1). Each counting area was a $2 \mathrm{~mm}$ square box on the magnified montage representing approximately $3-5 \%$ of the total saccular area, depending on the size of the saccule; the total hair cell count was extrapolated by a simple ratio. The number of cells was counted by two different investigators to ensure accuracy and never differed by more than $3 \%$ between investigators. Values reported are the averages of the two counters.

BrdU and TUNEL labeling. Saccules were dissected from zebrafish that had received one injection of BrdU ( $1 \mathrm{mg} / 10 \mathrm{~g}$ body weight; Sigma-Aldrich, St Louis, MO) 3 hours prior to sacrifice. At least six specimens were used for each age group other than 27 month old 
A

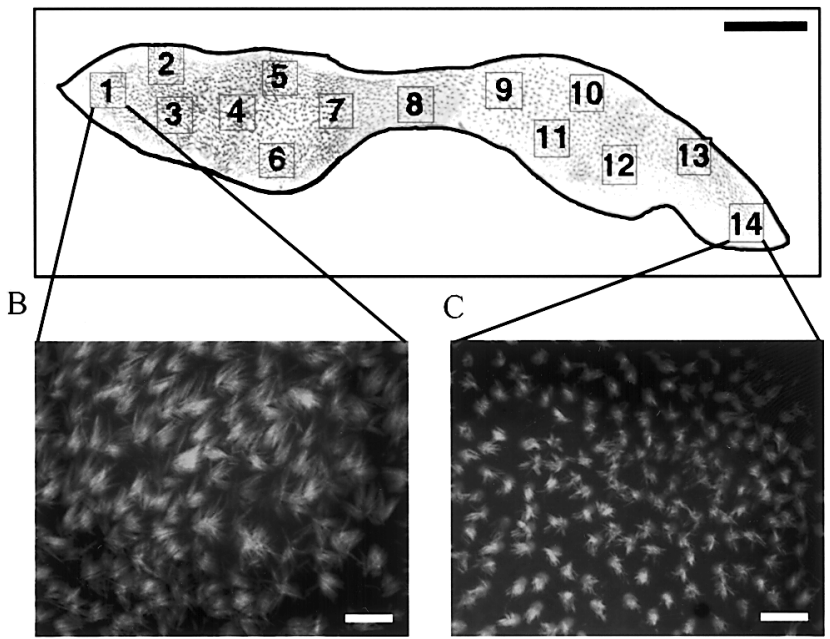

FIG. 1. A Confocal negative image of a montage of a complete phalloidin-stained saccular epithelium from a zebrafish (anterior is to the right, ventral to the top). To determine the number of cells and their density, higher magnification images (400X) were taken at the 14 marked locations and the number of cells in these areas were extrapolated to the full epithelium. B and C show 1000X magnification confocal images from two locations to show typical hair cell bundle distributions. Scale bar in $\mathbf{A}=100 \mu \mathrm{m}$, scale bars in $\mathbf{B}$ and $\mathbf{C}=10 \mu \mathrm{m}$.

animals, where only three fish were available. In addition, seven 15 month old uncrowded zebrafish were injected with BrdU and allowed to survive for 5 days to determine if at least some of the proliferating cells differentiated into mature hair cells. After treatment, the ears were exposed as described above and fixed for $40 \mathrm{~min}$ in $2.0 \%$ paraformaldehyde. Labeling with BrdU was detected using immunocytochemistry, as described previously (Wilkins et al. 1999). Briefly, tissue was processed with $0.05 \%$ collagenase for $5 \mathrm{~min}$, followed by $10 \mathrm{~N} \mathrm{HCl}$ for $20 \mathrm{~min}, 1 \% \mathrm{H}_{2} \mathrm{O}_{2}$ for 15 min, $10 \%$ goat serum for $15 \mathrm{~min}$, anti-BrdU overnight, secondary antibody (Sigma-Aldrich), peroxidaseantiperoxidase (Sigma-Aldrich), and diaminobenzidine (DAB, Sigma-Aldrich). All solutions contained $1 \%$ Triton X-100.

Saccules from another group of fish were used for detection of dying cells using the TUNEL protocol (Apoptag kit, Intergen Company, Purchase, NY). At least four specimens were used at all age groups other than 15 months, where only two fish were available. Tissue was fixed in $2.0 \%$ paraformaldehyde and processed as outlined in Wilkins et al. (2001). Tissues were first treated with $33 \%$ glacial acetic acid in $100 \%$ ethanol for $5 \mathrm{~min}$ followed by treatment with $0.09 \%$ $\mathrm{H}_{2} \mathrm{O}_{2}$ for $5 \mathrm{~min}$. The DNA was labeled with digoxigenin-conjugated nucleotides through the use of terminal deoxynucleotidyl transferase enzyme as outlined in the Apoptag kit. Tissue was then treated with peroxidase-conjugated antidigoxigenin followed by application of DAB to stain labeled cells dark brown.

All tissue from BrdU and TUNEL processing was dehydrated, embedded in plastic (Immunobed, Polysciences, Inc., Warrington, PA) and sectioned at $5 \mu \mathrm{m}$. Labeled cells were counted in sections manually under a Zeiss compound microscope at $200 \mathrm{X}$ magnification. If the same cell was labeled in two adjacent sections, it was counted as one labeled cell.

\section{Measurement of hearing capabilities}

Auditory thresholds were measured from ten zebrafish, which ranged from 27 to $47 \mathrm{~mm}$ in total length (TL), using the auditory brainstem response (ABR). This technique is a noninvasive method of measuring the whole brain response to auditory stimuli (Hall 1992) and is commonly used to measure auditory response thresholds in fish and other vertebrates (e.g., Corwin et al. 1982; Kenyon et al. 1998).

Each zebrafish was restrained in a mesh sling and suspended in a $19 \mathrm{~L}$ plastic bucket filled with water. A continuous flow of water was maintained over the gills of the animal with a respirator placed into the mouth. The respirator also helped to keep the fish's head stable during recording. The fish was suspended approximately $25 \mathrm{~cm}$ above an underwater speaker (UW-30, Underwater Sound Inc., Oklahoma City, OK).

A reference electrode was placed on the dorsal surface of the fish's head, between and slightly behind the eyes. A recording electrode was placed on the dorsal surface of the fish, just behind the brainstem. A ground electrode was placed in the water near the body of the fish to reduce background noise. Electrodes were stainless steel (Rochester Electro-Medical Inc., Tampa, FL) and insulated with fingernail polish, except for the very tip. The fish and all electrodes were kept a minimum of $5 \mathrm{~cm}$ below the water surface to minimize surface effects.

Sounds were played and responses collected through a Tucker-Davis Technologies Inc. (TDT, Gainesville, FL) physiology apparatus using SigGen and BioSig software (TDT). Sounds were played from a computer with the TDT software through a power amplifier connected to the UW-30 underwater speaker. Calibration of frequencies was accomplished each day by analyzing the output of each frequency with a LC10 hydrophone (calibration sensitivity of $-208.6 \mathrm{~dB}$ re: $1 \mathrm{~V} / \mu \mathrm{Pa}$; $\pm 3 \mathrm{~dB}, 0.1-180 \mathrm{kHz}$, omnidirectional) attached to a digital oscilloscope. Tone bursts were played at 100, 200, 400, 600, 800, 1000, 2000, and 4000 $\mathrm{Hz}$ for all fish. A few fish were also tested at $8000 \mathrm{~Hz}$ $(n=5)$ and $16,000 \mathrm{~Hz}(n=3)$, but this was discontinued once it was determined that zebrafish never responded to sounds above $4000 \mathrm{~Hz}$. Tone bursts had 
a $2 \mathrm{~ms}$ rise and fall time, were $10 \mathrm{~ms}$ in duration, and were gated through a Hanning window-conditions similar to those used in other ABR studies (e.g., McFadden et al. 1996; Yan et al. 2000; Mann et al. 2001). While there were somewhat broad sidebands in the signals below $800 \mathrm{~Hz}$, the level of the second harmonic was at least $15 \mathrm{dbV}$ lower than the fundamental output frequency, even at the lowest frequencies used.

Responses to each tone burst at each sound pressure level were collected by the BioSig software package, with 400 responses averaged for each presentation. Sound intensity levels at each frequency were increased in $5 \mathrm{~dB}$ steps until a stereotypical ABR spike was achieved. Responses were judged by eye, and detection was defined as being able to see a spike above background in the stereotypical ABR responses (Fig. 2). This qualitative assessment is commonly used in ABR studies (Hall 1992; Kenyon et al. 1998), and results obtained in this manner do not differ from results using more quantitative methods (Mann et al. 2001). We have also found that this method gives consistent results between investigators in our laboratory. For presentation, response averages were high-pass filtered at $30 \mathrm{~Hz}$ and low-pass filtered at $3000 \mathrm{~Hz}$ to remove high frequency noise. Threshold was defined as the lowest sound level giving a defined response. Since results of physiological hearing tests can vary between laboratories (Popper et al. 1973; Fay 1988a), we needed to be able to have some basis for comparing our results with thresholds determined for other fishes. As there is a large body of data on hearing sensitivity in goldfish (Carassius auratus), we determined thresholds for this species ( $n=3$, TL approximately $70 \mathrm{~mm}$ ) using the identical procedures used for zebrafish as a way to compare data for zebrafish with other species in the literature.

As a final control to assure that the responses were actually from the auditory system, we made recordings from both whole dead zebrafish and isolated trunk musculature of dead fish. In no case did these recordings give responses that in any way resembled the responses from the brain of living fish (Fig. 2C).

\section{Statistical analyses}

All statistical analyses were done as analyses of variance (ANOVA) with the Tukey post hoc test as followup when significant differences were found (Zar 1984), except

FIG. 2. Auditory brainstem response traces (after low-pass filtering at $3000 \mathrm{~Hz}$ ) to an (A) $100 \mathrm{~Hz}$ tone burst and an (B) $800 \mathrm{~Hz}$ tone burst in an adult zebrafish. Auditory threshold was judged as the lowest intensity showing a defined response $(140 \mathrm{~dB}$ at $100 \mathrm{~Hz}$ and $125 \mathrm{~dB}$ at $800 \mathrm{~Hz}$ for this individual). Dead fish controls never gave a response similar to an $\mathrm{ABR}(\mathbf{C})$. All intensity values are $\mathrm{dB}$ re $1 \mu \mathrm{Pa}$.
A $100 \mathrm{~Hz}$

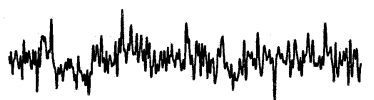

$130 \mathrm{~dB}$

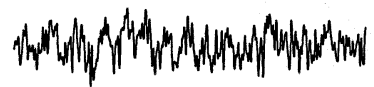

$135 \mathrm{~dB}$

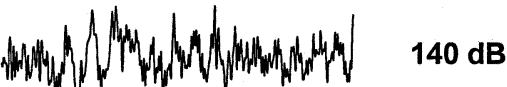

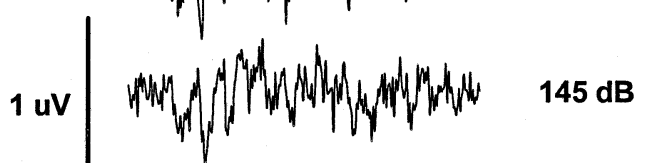
$10 \mathrm{~ms}$

B

$800 \mathrm{~Hz}$
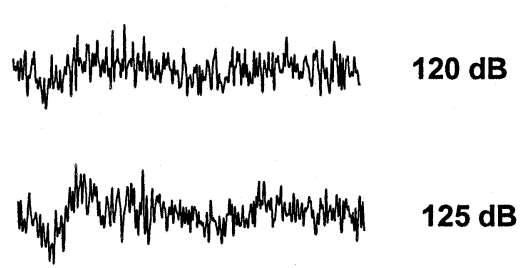

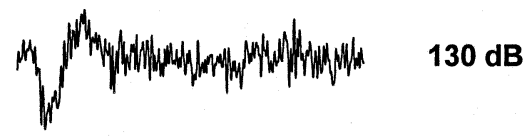

$1 \mathrm{uV} \sum_{10 \mathrm{~ms}}$

C

\section{Control}

$100 \mathrm{~Hz}-150 \mathrm{~dB}$

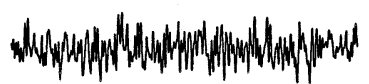

$800 \mathrm{~Hz}-135 \mathrm{~dB}$

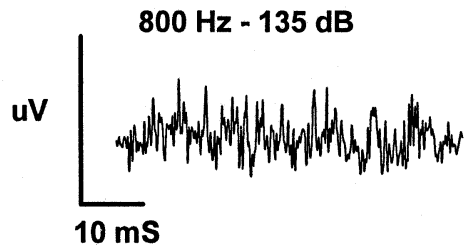




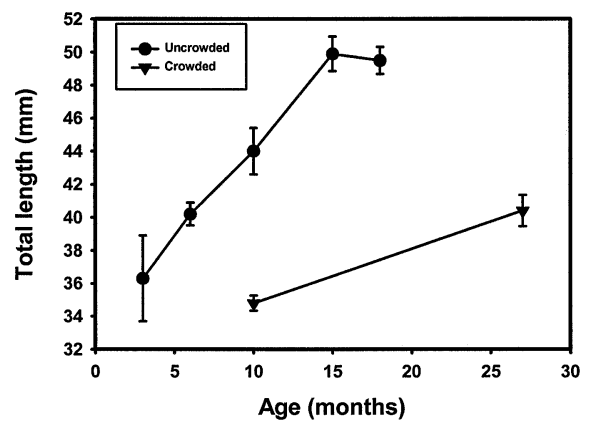

FIG. 3. Mean ( \pm 1 S.E.) fish growth for crowded and uncrowded zebrafish. Between 11 and 17 animals were used for each mean, except for 27 months for which only 6 animals were available.

for comparisons of crowded versus uncrowded animals, which were compared with a Student's $t$-test. For comparisons of auditory threshold, animals were put into one of three size classes: $25-34 \mathrm{~mm}(n=4)$, $35-44 \mathrm{~mm}(n=4)$, and $45-50 \mathrm{~mm}(n=2)$. For auditory thresholds, a 2-factor ANOVA was performed with frequency and size class as the independent variables. Means are given with plus or minus one standard error when provided. For the morphological parameters, all ANOVAs were done as single factor. For all tests, $\alpha=0.05$ was used as the significance level.

\section{RESULTS}

\section{Growth}

Fish kept in the uncrowded tanks showed significant increases in size up to 15 months of age $(P<0.01)$ but no significant change in size between 15 and 18 months $(P>0.05$; Fig. 3$)$. Fish in crowded conditions showed a significant increase in length between 10 and 27 months of age $(P<0.001)$, but they never reached the length of 10 month old uncrowded fish (Fig. 3). What is most interesting, however, is that at the one time period for which statistical comparisons are possible for uncrowded and crowded fishes-10 months of age, the crowded fish averaged $35( \pm 0.11)$ $\mathrm{mm}$ in total length, while uncrowded fish averaged $44( \pm 0.36) \mathrm{mm}$. This difference was significant in a Student's $t$-test $(P<0.001)$.

The total saccular area of uncrowded fish increased up to 10 months of age (Fig. 4A). Although there was some continued growth after 10 months, changes in area after 10 months were not significant $(P>0.05)$. The saccular area of 10 month crowded fish was significantly smaller $\left(0.13 \pm 0.004 \mathrm{~mm}^{2}\right)$ than that of uncrowded animals $\left(0.20 \pm 0.014 \mathrm{~mm}^{2}\right)(P<0.001)$. Due to the variability in length at a given age (Fig. 3 and see Discussion), we also examined morphological parameters relative to fish total length. When expressed as a function of fish length, with crowded and uncrowded animals considered together, there was a significant increase in saccular area with growth of the fish $(P<0.001)$, with fish smaller than $42 \mathrm{~mm}$ having significantly smaller saccules than those larger than $42 \mathrm{~mm}(P<0.01$, Fig. 4B).

In uncrowded fish, there was a significant increase in the number of hair cells with age $(P<0.02)$, with numbers changing little after 10 months of age (Fig. $4 \mathrm{C})$. There were significantly fewer $(P<0.05)$ hair cells in 10 month old crowded fish $(2541 \pm 75)$ than in the same-age fish raised in uncrowded conditions (3560 \pm 175 , Fig. 4C). When crowded and uncrowded animals were considered together and hair cell number was expressed as a function of fish total length, there was a significant increase $(P<0.01)$ in hair cell number with total length in zebrafish. Animals smaller than $42 \mathrm{~mm}$ tended to have fewer hair cells than those larger than $42 \mathrm{~mm}$, although there were few significant differences between individual size classes (Fig. 4D).

Confocal images suggested that there were density differences in hair cells along the length of the saccular epithelium. These differences were compared by plotting the number of cells in each of the 14 regions examined (Fig. 1). Figure 5 shows that the density of cells was considerably greater at the caudal end of the epithelium than at the rostral end for all of the size groups examined. Crowded and uncrowded fish had the same density distribution within the counted areas, and the relative densities at different regions did not change as the fish grew (Fig. 5).

\section{Cell division and death}

Cells labeled with BrdU were found in the saccular epithelia of all fish examined (Fig. 6A, B), and what appeared to be labeled mature hair cells were found in the animals allowed to survive for 5 days after injection (Fig. 6C). In the animals with $3 \mathrm{~h}$ postinjection exposure, there was a significant effect of age on the number of BrdU-labeled cells in uncrowded animals $(P=$ 0.01 ) but no effect of age between the two groups of crowded animals $(P>0.05$, Fig. 7A). There were significantly more $(P<0.01)$ BrdU-labeled cells in the 10 month old uncrowded $(9.8 \pm 1.5)$ than in the 10 month old crowded $(3.5 \pm 0.8)$ animals. When the number of BrdU-labeled cells was expressed as a function of fish total length regardless of age or growing conditions (Fig. 7B), there was a significant increase in the number of labeled cells with fish length $(P<$ 0.03). Animals smaller than $42 \mathrm{~mm}$ had fewer labeled cells than those larger than $42 \mathrm{~mm}$, although there were few significant differences between individual size classes.

The number of dying cells detected using the 
TUNEL assay (Figs. 7 and 8) remained at a steady, and relatively low, level through all age groups and sizes of fish, with no significant effect of age, length, or crowding on the number of TUNEL-labeled cells (Fig. $7 \mathrm{~A}, \mathrm{~B} ; P>0.5)$.

\section{Hearing capabilities}

The results from the ABR threshold determinations are shown in Figure 9 relative to total length, since this was a better predictor of hair cell number than was age. There was no significant difference $(P>0.05)$ in auditory threshold between the three size classes of fish (Fig. 9A), nor was there a significant interaction between frequency and threshold $(P>0.05)$. There was a significant effect of frequency on threshold $(P<0.001)$. For all fish tested, tone detection ranged from $100 \mathrm{~Hz}$ (the lowest frequency tested) to $4000 \mathrm{~Hz}$, with best sensitivity between 600 and $1000 \mathrm{~Hz}$. Data for all fish $(n=10)$ were pooled (since there was no significant effect of size on detection thresholds) to give an average audiogram for juvenile and adult zebrafish (Fig. 9B). Zebrafish had a best frequency of 800 $\mathrm{Hz}$, with a mean sensitivity of $127( \pm 3.6) \mathrm{dB}$ re $1 \mu \mathrm{Pa}$ at this frequency in our testing apparatus. Sensitivity decreased (threshold increased) at frequencies lower and higher than $800 \mathrm{~Hz}$. There were no auditory responses to stimuli above $4000 \mathrm{~Hz}$ in our system.

The responses of zebrafish in our testing apparatus were generally similar to adult goldfish measured in the same experimental apparatus (Fig. 9B). Both species had best frequencies of $800 \mathrm{~Hz}$ with a mean sensitivity of approximately $130 \mathrm{~dB}$ re $1 \mu \mathrm{Pa}(133.3$ $\pm 3.33 \mathrm{~dB}$ for goldfish) and an auditory bandwidth of $100-4000 \mathrm{~Hz}$. Analysis of the complete audiograms showed that, overall, the goldfish is slightly less sensitive than the zebrafish $(P<0.05)$, although the only large difference between the two species was at $2000 \mathrm{~Hz}$.

\section{DISCUSSION}

Our results demonstrate that zebrafish, like other teleost fishes (Popper and Hoxter 1984; Lombarte

FIG. 4. Changes in saccular area and hair cell number with age and growth of zebrafish. A Saccular area changes with age in uncrowded fish and is significantly larger at 10 months in uncrowded than in crowded fish. B Saccular area significantly increased with zebrafish total length. $\mathbf{C}$ The number of hair cells also continued to increase to about 10 months of age in uncrowded fish, and the number of cells was much greater in uncrowded than in crowded fish. $\mathbf{D}$ In terms of length, hair cell number increased in fish up to $44 \mathrm{~mm} \mathrm{TL}$, leveling off after this size. All symbols represent mean ( \pm 1 S.E.) based on 4-6 animals, except for 18 months (49 mm TL) for which only 3 animals were used.

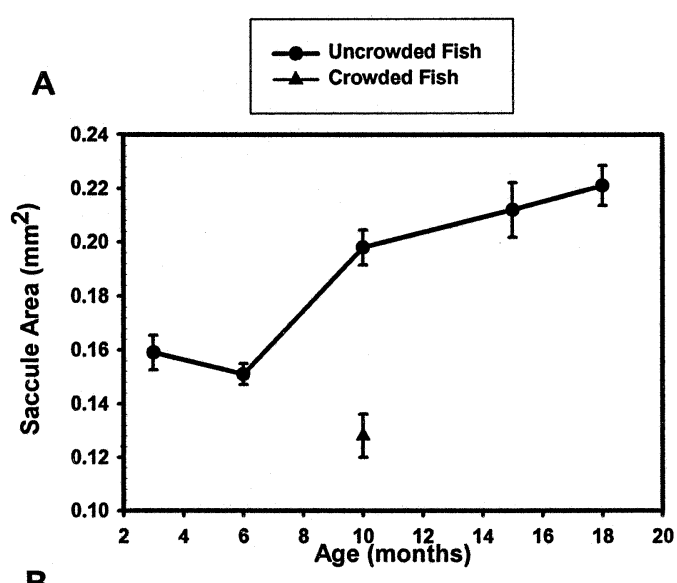

B
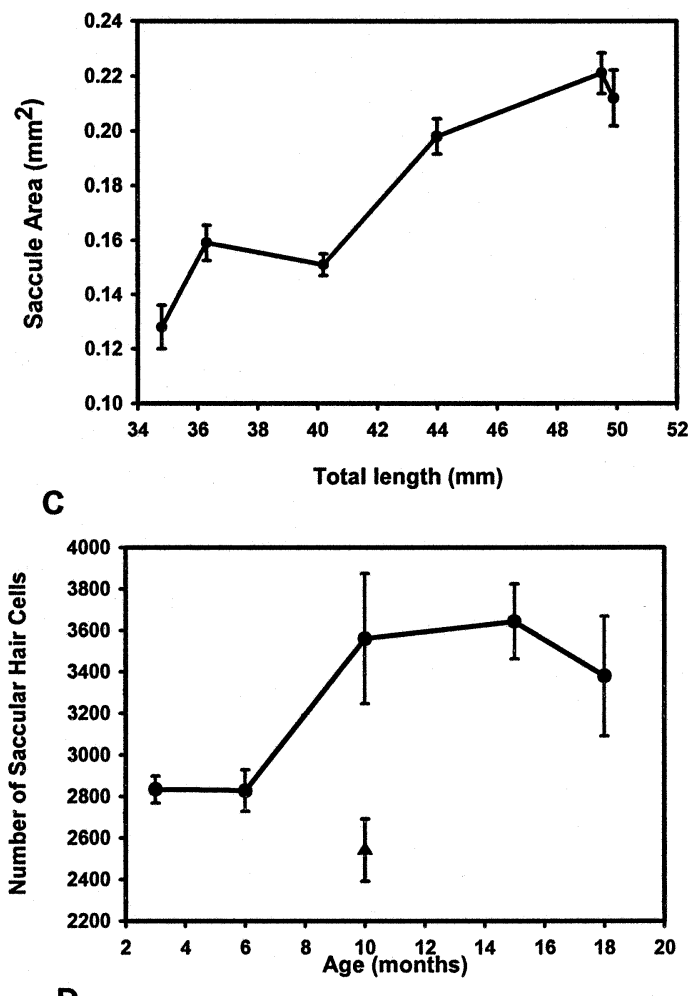

D

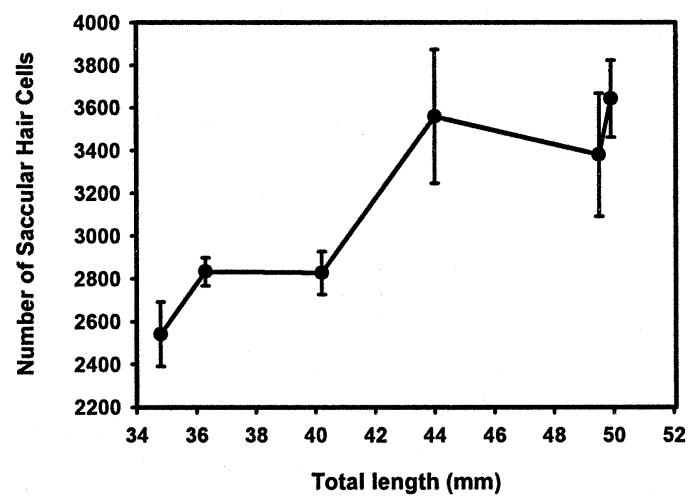




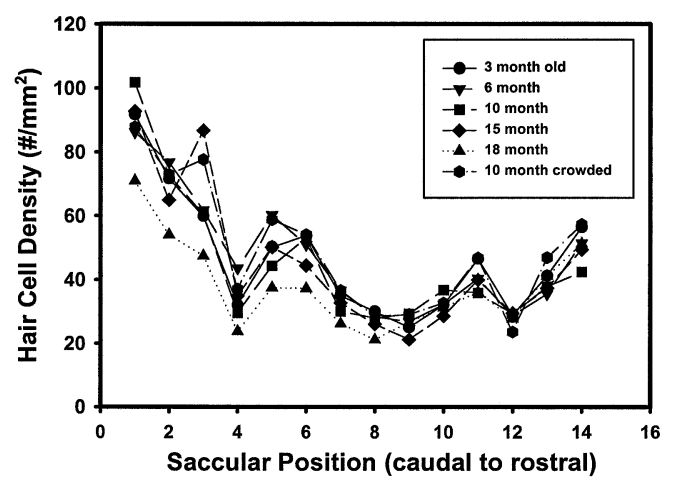

FIG. 5. Density of hair cells from caudal to rostral ends of the saccular epithelium. The saccular positions on the x-axis correspond with the positions shown on the confocal image in Fig. 1. The same average density was found in both crowded and uncrowded fish. Number of animals is the same as in Fig. 4.

and Popper 1994), continue to add hair cells to the saccular sensory epithelium well past hatching. Moreover, our study also demonstrates that the total number of hair cells stabilizes in zebrafish but that after stabilization cell proliferation continues. In addition, the auditory bandwidth of zebrafish is essentially the same as for other otophysan fishes and, despite changes in hair cell number with fish growth, there is no change in hearing capabilities through the range of sizes tested here.

Hair cell numbers seem to stabilize at about 10 months of age in uncrowded animals. The one previous study that examined hair cell addition in zebrafish found a linear increase in hair cell number from 75 to 168 hours after fertilization (Haddon and Lewis 1996). Zebrafish 168 hours postfertilization have approximately 80 hair cells in the saccule (Haddon and Lewis 1996); in our study they had 2800 hair cells by 3 months postfertilization. This represents an addition of over 850 cells per month if these two studies are comparable. By 10 months this addition has stabilized. Earlier studies on hair cell addition in nonotophysan fishes suggested that cells may continue to be added for much of the life of elasmobranchs (Corwin 1981), cichlids (Astronotus ocellatus, Popper and Hoxter 1984), and the hake (Merluccius merluccius, Lombarte and Popper 1994). It is possible that zebrafish stop growing much earlier than other species, perhaps because of the small size at adulthood.

Our results show that there is no increase in the number of hair cells in uncrowded zebrafish after 10 months (44 mm TL). However, the TUNEL results showing loss of cells (it was not possible to tell if dying cells were hair cells or supporting cells) and the BrdU results showing a small number of new cells in larger fish suggest that there may be a low level of turnover in hair cells and supporting cells. Thus, new
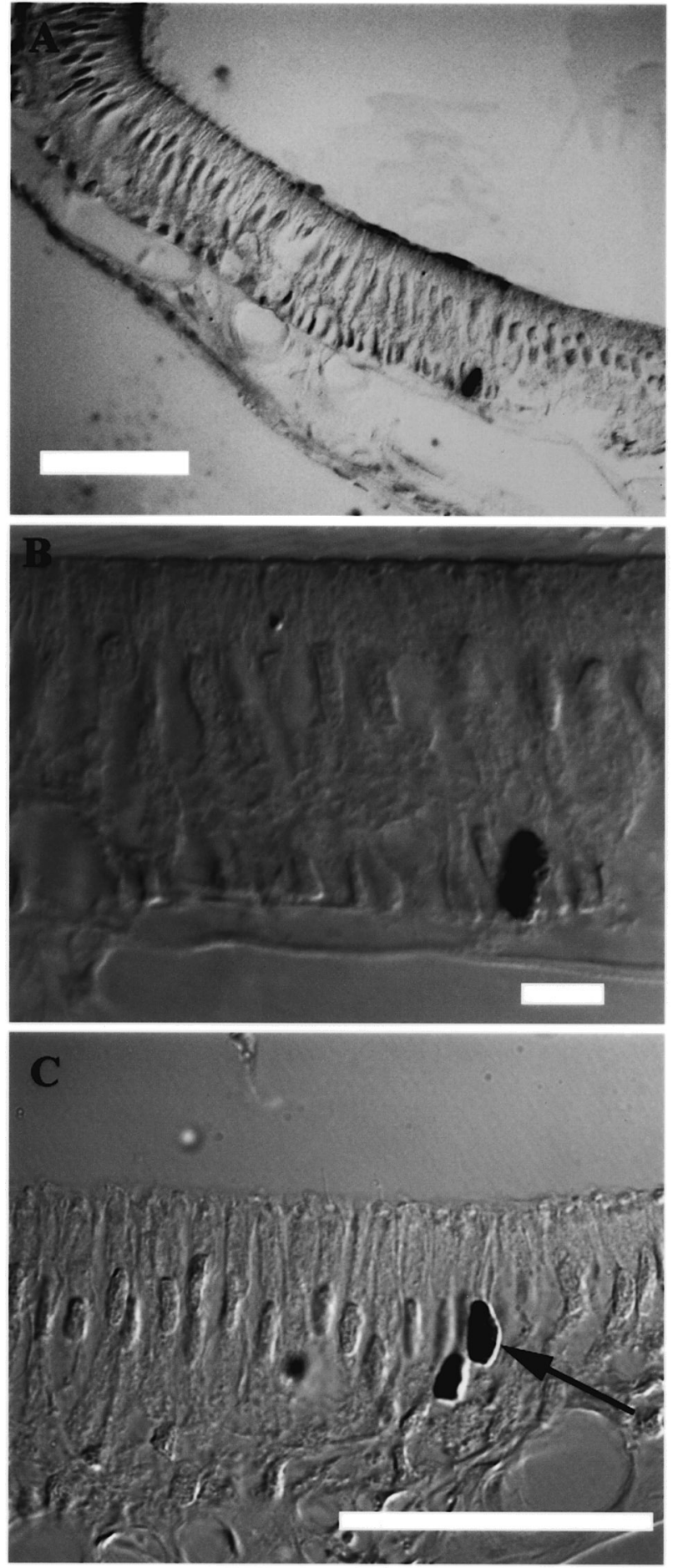

FIG. 6. S-phase cells in the zebrafish saccule labeled by BrdU. A An example of a BrdU-labeled supporting cell (black) at 200X. B The same BrdU-labeled cell at 1000X. C Labeling with BrdU of what appears to be a mature hair cell (arrow) at 400X. Scale bars in $\mathbf{A}$ and $\mathbf{C}=100 \mu \mathrm{m}$, scale bar in $\mathbf{B}=10 \mu \mathrm{m}$.

hair cells produced after $44 \mathrm{~mm}$ TL probably just replace dying cells, suggesting that in fishes, unlike mammals, there may be a mechanism to maintain a constant hair cell number even into relatively old 


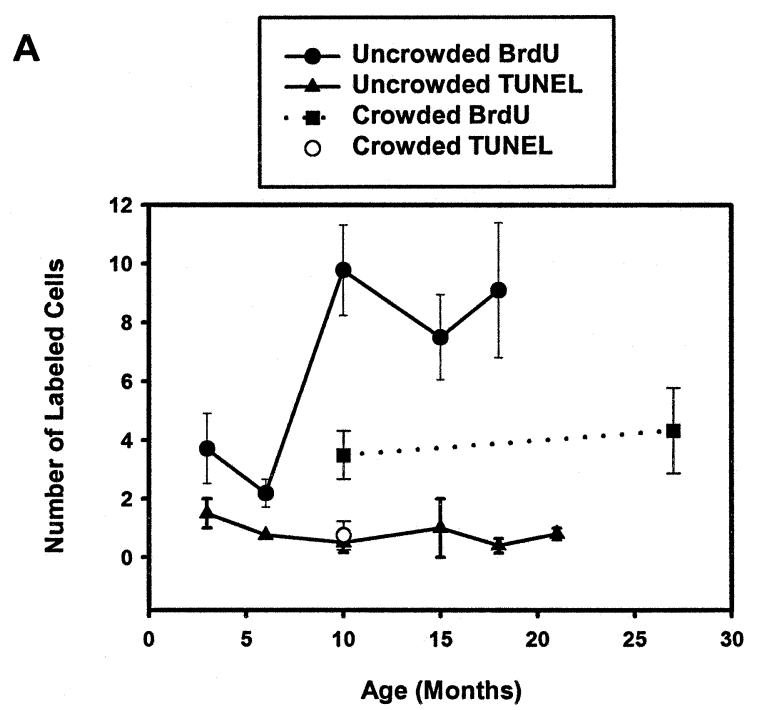

B

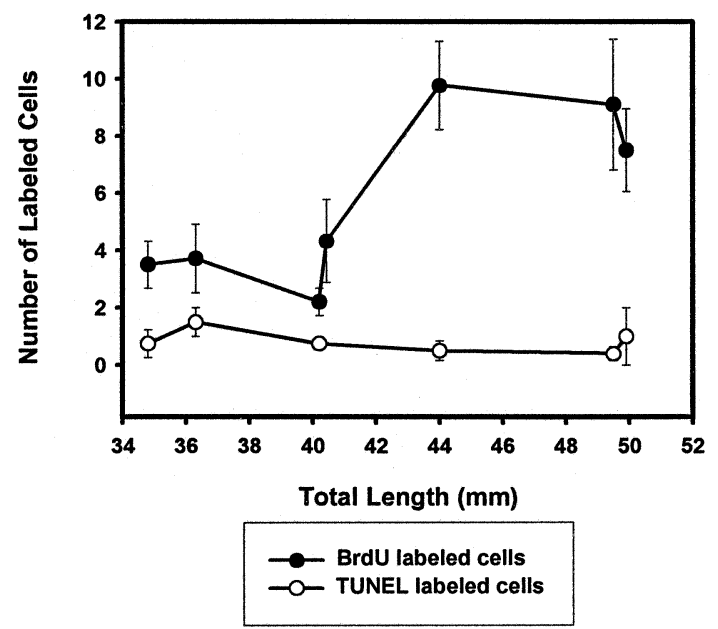

FIG. 7. Changes in BrdU- and TUNEL-labeled cells in the zebrafish saccular epithelium. A The number of BrdU-labeled cells increased up to 10 months of age and then stabilized in uncrowded animals while there was no significant change in BrdU label in crowded animals. B When crowded and uncrowded animals were considered together, the number of BrdU-labeled cells increased with length, with the largest increase occurring after $42 \mathrm{~mm}$ TL. The number of TUNEL-labeled cells stayed constant and small throughout ontogeny (A and B). All symbols represent mean ( \pm 1 S.E.).

age. The nonsignificant increase in saccular area after $44 \mathrm{~mm}$ may be due to increases in supporting cell numbers, since hair cell numbers have stabilized while cell proliferation is continuing, or to increases in size of supporting or hair cells.

\section{Implications for crowding on zebrafish growth}

Our results also demonstrate that the size of zebrafish, the number of sensory hair cells, and the rate of cell proliferation in the ear are dramatically affected by

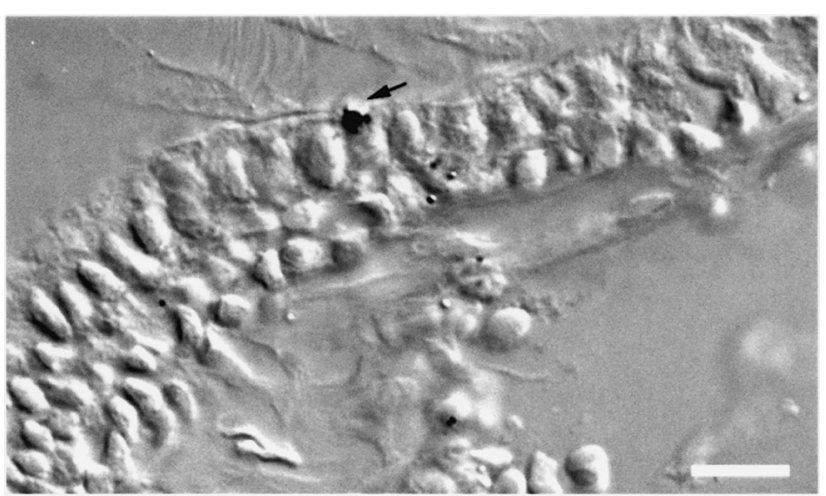

FIG. 8. Using the TUNEL procedure, we find that there is a population of cells in the saccular epithelium undergoing apoptosis, as shown at arrow. Preliminary evidence suggests that apoptosis occurs in saccules from zebrafish aged 3, 6, 10, 15, 18, and 21 months. Scale bar $=10 \mu \mathrm{m}$.

conditions under which fish are kept. While we cannot stipulate that fish in our uncrowded groups grew as much as would fish in the wild, it is clear that the fish in our uncrowded conditions grew far faster and far larger than fish under our crowded conditions. The implications of this finding are significant for all future studies of growth and aging in zebrafish, and possibly even for early developmental studies. Clearly, factors such as fish size, rate of cell proliferation, and other changes will be affected by the extent of crowding of the fish being studied. It should also be noted that the number of fish in our crowded tanks is very close to the level recommended for general zebrafish care (Westerfield 1995).

Our results also point out the need for a better metric than age for studies of fish development. Our two groups (crowded vs. uncrowded) of 10 month old fish had significantly different numbers of hair cells and significantly different numbers of proliferating cells. Thus, saying a fish is 10 months old tells little about the developmental state of the animal, as a 10 month old fish could represent a wide range of developmental stages and have vastly different sensory morphology depending on rearing conditions. Total length is a much better indicator of developmental progress than age in posthatching fish (Fuiman et al. 1998), and the use of age makes comparison between species especially problematic. As shown by our data on the effects of crowding and by previous studies (Zweifel and Lasker 1976; Chambers and Leggett 1987; Vollestad 1992), it would be helpful if researchers not use age as a metric in studies of posthatching fish development but instead use length or, better, the ontogenetic index of Fuiman et al. (1998), which expresses larval development as a percentage of the larval period elapsed. 

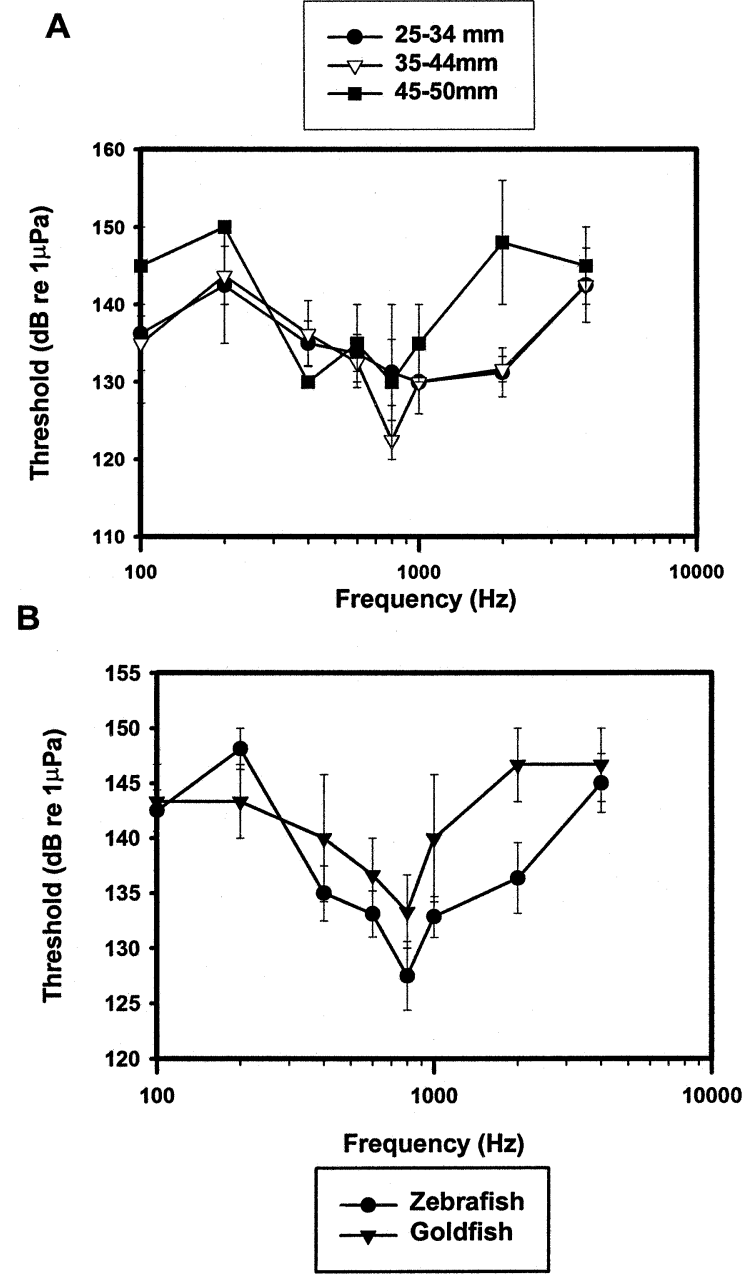

FIG. 9. Audiograms based on ABR for (A) fish of 25-34 $\mathrm{mm}(n=$ 4), 35-44 mm $(n=4)$, and $45-50 \mathrm{~mm}(n=2)$ and (B) a composite audiogram from juvenile and adult zebrafish based on pooling of the individual audiograms shown in $\mathbf{A}(n=10)$. Zebrafish were slightly more sensitive (lower thresholds) than goldfish (B) examined using the identical methods, including electrode placement. All symbols represent mean ( \pm 1 S.E.).

\section{Hearing capabilities}

The current study is the first that provides data on zebrafish hearing abilities. There were no differences in auditory threshold, bandwidth, or best frequency for zebrafish over the size range examined in this study (34-50 mm TL), despite differences in hair cell number and saccular area. That there were no changes in auditory sensitivity with changes in fish size is interesting. Rays (Raja clavata) show an increase in physiological sensitivity of the auditory nerve that is concomitant with an increase in hair cell number (Corwin 1983), and other species show increased auditory sensitivity with age in very young fish (Kenyon 1996; Wysocki and Ladich 2001). There was a significant increase in hair cell number in zebrafish examined in the current study and yet no discernible effect on auditory threshold. There are several possible explanations for the changes encountered in previous studies and the lack of change in our animals. First, and most obviously, there are differences in the species used. Second, the techniques used for the elasmobranch and those used in the current study were very different. Corwin (1983) looked at the specific output of the ear using compound action potentials measured in the eighth cranial nerve, while we looked at the evoked response from the brainstem. Evoked brainstem responses presumably integrate information from the whole ear, processing in the brainstem, and, possibly, the output of both ears to the brain and influences from higher brain centers on the brainstem. Third, the fish used in other studies may have been younger than those used here.

The significant question to ask concerns the lack of correlation between hair cell increase in our fishes and change in hearing capabilities. One explanation is that while there may potentially be a greater response in the eighth nerve with number of hair cells in the ear (as per the findings in the ray), the result of higher level processing and combination of inputs from various receptors may eliminate the differences. Indeed, one model of fish hearing predicts that there must be an increase in hair cell number in order to maintain a stable hearing threshold as fish grow and the distance between the ear and peripheral structures (e.g., the swim bladder) increases (Popper et al. 1988; Rogers et al. 1988; Fineran and Hastings 2000). An alternative though less compelling hypothesis is that the increase in hair cells impacts other aspects of hearing, such as discrimination capabilities, and this would not have shown up in our audiometric studies.

The zebrafish audiogram does not show any appreciable differences from that for goldfish in our testing apparatus. This was not surprising since both species are in the same taxonomic family (Cyprinidae) and have similar inner ear anatomy and ultrastructure (Platt 1977, 1993). Most importantly, the zebrafish, like other otophysan fishes, have a series of bones, the Weberian ossicles, which connect the pressuredetecting swim bladder to the inner ear. This special connection is known to enhance hearing in otophysan fishes as compared with other species (Fay 1988b; Popper and Fay 1999), so it is not surprising that zebrafish have good hearing.

There are differences in auditory sensitivity, but not bandwidth, of goldfish in our apparatus as compared with previous reports. Kenyon et al. (1998), also using ABR, found a similarly shaped audiogram as ours for goldfish, with response bandwidth from 100 to 5000 $\mathrm{Hz}$ and a best frequency of $1000 \mathrm{~Hz}$, but thresholds were $20-60 \mathrm{~dB}$ lower in their system. This is probably due to differences in testing apparatus. We feel that 
comparisons of auditory sensitivity are difficult between laboratories, whether with $\mathrm{ABR}$ or with other measures. Fay (1988a) found a $50 \mathrm{~dB}$ difference in sensitivity and Popper et al. (1973) found up to $30 \mathrm{~dB}$ difference in thresholds between experimenters with goldfish. In our apparatus we have found sensitivity differences up to $40 \mathrm{~dB}$ in tests on the American shad (Alosa sapidissima) simply by varying the depth of electrode placement (unpublished data). Thus, measures of auditory sensitivity are useful only on a comparative basis in the same experimental conditions. What is of interest between investigators is the bandwidth, the shape of the audiogram, and the frequency of best sensitivity. In these three respects there is good agreement between our goldfish data and previous investigations (Popper 1971; Fay 1988a; Kenyon et al. 1998), validating our results for zebrafish.

\section{ACKNOWLEDGMENTS}

The work reported here was supported by grant AG015681 from the National Institute on Aging of the NIH (ANP) and grant DC04502-01 from the National Institute on Deafness and other Communicative Disorders of the NIH (DMH). Additional support was provided for DMH and HRW by training grant DC-00046 from the National Institute on Deafness and Other Communicative Disorders of the NIH. We want to thank Tim Maugel for help with microscopy and two anonymous reviewers for comments on the manuscript.

\section{REFERENCES}

Boatright-Horowitz SS, Megela Simmons A. Postmetamorphic changes in auditory sensitivity of the bullfrog midbrain. J. Comp. Physiol. A 177:577-590, 1995.

Chambers RC, LeggetT WC. Size and age at metamorphosis in marine fishes: an analysis of laboratory-reared winter flounder (Pseudopleuronectes americanus) with a review of variation in other species. Can. J. Fish. Aquat. Sci. 44:1936-1947, 1987.

CORWIN JT. Postembryonic production and aging in inner ear hair cells in sharks. J. Comp. Neurol. 201:541-553, 1981.

CoRWIN JT. Postembryonic growth of the macula neglecta auditory detector in the ray, Raja clavata: Continual increases in hair cell number, neural convergence, and physiological sensitivity. J. Comp. Neurol. 217:345-356, 1983.

CORWIN JT, COTANCHE DA. Regeneration of sensory hair cells after acoustic trauma. Science 240:1772-1774, 1988.

Corwin JT, Bullock TH, SCHWEITZER J. The auditory brain stem response in five vertebrate classes. Electroencephalogr. Clin. Neurophysiol. 54:629-641, 1982.

COTANCHE DA. Regeneration of hair cell stereociliary bundles in the chick cochlea following severe acoustic trauma. Hear. Res. 30:181-195, 1987.

CRUZ RM, LAMBERT PR, RUBel EW. Light microscopic evidence of hair cell regeneration after gentamicin toxicity in chick cochlea. Arch. Otolaryngol. Head Neck Surg. 130:1058-1062, 1987.

FAY RR. Hearing in Vertebrates: a Psychophysics Databook. Hill-Fay Winetka, IL, 1998a.

FAY RR. Peripheral adaptations for spatial hearing in fish. In: Atema
J, Fay RR, Popper AN, Tavolga WN, (eds) Sensory Biology of Aquatic Animals. Springer-Verlag New York, 1988b, p. 712-731.

FinerAN JJ, HASTINGS MC. A mathematical analysis of the peripheral auditory system mechanics in the goldfish (Carassius auratus). J. Acoust. Soc. Am. 108:1308-1321, 2000, DOI: 10.1121/1.1286099.

Fuiman LA, Poling KR, Higgs DM. Quantifying developmental progress for comparative studies of larval fishes. Copeia 1998:602611, 1998.

Golubeva TB, Tikhonov AV (1985) The voice and hearing of birds in ontogeny. In: Acta XVIII International Ornithology Congress Nauka, Moscow, pp. 259-274.

Granato M, van Eeden FJM, Schach U, Trowe T, Brand M, Furutani-Sekei M, Haffter P, Hammerschmidt M, Heisenberg CP, Jiang Y-J, Kane DA, Kelsh RN, Mullins MC, Odenthal J, NÜSSLEIN-VOLHARD C. Genes controlling and mediating locomotion behavior of the zebrafish embryo and larva. Development 123:399-413, 1996.

Haddon C, Lewis J. Early ear development in the embryo of the zebrafish, Danio rerio. J. Comp. Neurol. 365:113-128, 1996, DOI: 10.1002/(SICI) 1096-9861 (19960129)365:1<113::AIDCNE9>3.3.CO;2-A.

HALL JW III. Handbook of auditory evoked responses. Allyn \& Bacon Boston, MA, 1992.

Hill KG, CONE-Wesson B, LiU GB. Development of auditory function in the tammar wallaby Macropus eugenii. Hear. Res. 117:97106, 1998, DOI: 10.1016/S0378-5955(97)00211-6.

INNES WT. Exotic aquarium fishes. Innes Publishing Philadelphia, PA, 1956

Iwashita A, Sakamoto M, Kojima T, Watanabe Y, Soeda H. Growth effects on the auditory threshold of red sea bream. Nippon Suisan Gakkaishi 65:833-838, 1999.

JøRGENSEN JM, MATHIESEN C. The avian inner ear: continuous production of hair cells in vestibular sensory organs but not in the auditory papilla. Naturwissenschaften 75:319-320, 1988.

KENYON TN. Ontogenetic changes in the auditory sensitivity of damselfishes (pomacentridae). J. Comp. Physiol. A 179:553-561, 1996.

KENYON TN, LADICH F, YAN HY. A comparative study of hearing ability in fishes: the auditory brainstem response approach. J. Comp. Physiol. A 182:307-318, 1998, DOI: 10.1007/ s003590050181.

LOMbarte A, Popper AN. Quantitative analyses of postembryonic hair cell addition in the otolithic end organs of the inner ear of the European hake, Merluccius merluccius (Gadiformes, Teleostei). J. Comp. Neurol. 345:419-428, 1994.

Mann DA, Higgs DM, Tavolga WN, Souza MJ, Popper AN. Ultrasound detection by clupeiform fish. J. Acoust. Soc. Am. 109:30483054, 2001, DOI: 10.1121/1.1368406.

MCFAdDEN SL, WAlsh EJ, MCgEe J. Onset and development of auditory brainstem response in the Mongolian gerbil (Meriones unguiculatus). Hear. Res. 100:68-79, 1996, DOI: 10.1016/03785955 (96) 00108-6.

PlatT C. Hair cell distribution and orientation in goldfish otolith organs. J. Comp. Neurol. 172:283-297, 1977.

Platt C. Zebrafish inner ear sensory surfaces are similar to those in goldfish. Hear. Res. 65:133-140, 1993.

Platt C, Popper AN. Fine structure and function of the ear. In: Tavolga WN, Popper AN, Fay RR, (eds) Hearing and Sound Communication in Fishes. Springer-Verlag New York, 1981, p. 4-38.

POPPER AN. The effects of size on auditory capacities of the goldfish. J. Aud. Res. XI:239-247, 1971.

Popper AN, Hoxter B. Growth of a fish ear: 1. Quantitative analysis of sensory hair cell and ganglion cell proliferation. Hear. Res. 15:133-142, 1984.

POPPER AN, FAY RR. The auditory periphery in fishes. In: Fay RR, Popper AN, (eds) Comparative Hearing: Fish and Amphibians. Springer-Verlag New York, 1999, p. 43-100.

Popper AN, Chan ATH, Clarke NL. An evaluation of methods for 
behavioral investigations of teleost audition. Behav. Res. Meth. Instr. 5:470-472, 1973.

Popper AN, Rogers PH, SAidel WM, Cox M. The role of the fish ear in sound processing. In: Atema J, Fay RR, Popper AN, Tavolga WN, (eds) Sensory Biology of Aquatic Animals. Springer-Verlag New York, 1988, p. 687-710.

REIMER K. Ontogeny of hearing in the marsupial, Monodelphis domestica, as revealed by brainstem auditory evoked potentials. Hear. Res. 92:143-150, 1996, DOI: 10.1016/0378-5955(95) 00213-8.

Riley BB, GRUNWALD DJ. A mutation in zebrafish affecting a localized cellular function required for normal ear development. Dev. Biol. 179:427-435, 1996, DOI: 10.1006/dbio.1996.0272.

Riley BB, MoORMan SJ. Development of utricular otoliths, but not saccular otoliths, is necessary for vestibular function and survival in zebrafish. J. Neurobiol. 43:329-337, 2000, DOI: 10.1002/10974695(20000615) 43:4<329::AID-NEU2>3.0.CO;2-H.

Roberson DF, WeIsLeder P, Bohrer PS, RUBel EW. Ongoing production of sensory cells in the vestibular epithelium of the chick. Hear. Res. 57:166-174, 1992.

Rogers PH, Popper AN, Cox M, SAIDEL WM. Processing of acoustic signals in the auditory system of bony fish. J. Acoust. Soc. Am. 83:338-349, 1988.

RUBEN RJ. Development of the inner ear of the mouse: A radioautographic study of terminal mitoses. Acta Otolaryngol. Suppl. 220:144, 1967.

RÜBSAMEN R. Postnatal development of central auditory frequency maps. J. Comp. Physiol. A 170:129-143, 1992.

Ryals BM, RubEL EW. Hair cell regeneration after acoustic trauma in adult Coturnix quail. Science 240:1772-1774, 1988.

VOLLESTAD LA. Geographic variation in age and length at metamorphosis of maturing European eel: environmental effects and phenotypic plasticity. J. Anim. Ecol. 61:41-48, 1992.
WATERMAN RE, BELL DH. Epithelial fusion during early semicircular canal formation in the embryonic zebrafish, Brachydanio rerio. Anat. Rec. 210:101-114, 1984.

Werner YL, Montgomery LG, SAfford SD, Igic P, SAunders JC. How body size affects middle-ear structure and function and auditory sensitivity in gekkonoid lizards. J. Exp. Biol. 201:487-502, 1998.

WeSTERFIELD M. The Zebrafish Book, 3rd ed. University of Oregon Eugene, OR, 1995.

Whitfield TT, Granato M, van Eeden JM, Schach U, Brand M, Furutani-Seiki M, HaffTer P, Hammerschmidt M, HaisenberG C-P, Jiang Y-J, Kane DA, Kelsh RN, Mullins MC, Odenthal J, Nüsslein-Volhard C. Mutations affecting development of the zebrafish inner ear and lateral line. Development 123:241-254, 1996.

Wilkins HR, Presson JC, Popper AN. Proliferation of vertebrate inner ear supporting cells. J. Neurobiol. 39:527-535, 1999, DOI: 10.1002/(SICI) 1097-4695(19990615)39:4<527::AIDNEU6>3.3.CO;2-B.

Wilkins HR, Presson JC, Popper AN, Ryals BM, Dooling RJ. Hair cell death in a hearing-deficient canary. J. Assoc. Res. Otolaryngol. 2:79-86, 2001

WYSOCKI LE, LADICH F. The ontogenetic development of auditory sensitivity, vocalization and acoustic communication in the labyrinth fish Trichopsis vittata. J. Comp. Physiol. A 187:177-187, 2001.

YAN HY, FINE ML, HORN NS, COLÓN WE. Variability in the role of the gasbladder in fish audition. J. Comp. Physiol. A 186:435-445, 2000.

ZAR JH. Biostatistical Analysis, 2nd ed. Prentice-Hall Englewood Cliffs, NJ, 1984.

ZWEIFEL JR, LASKER R. Prehatch and posthatch growth of fishes-a general model. Fish. Bull. US 74:609-621, 1976. 